European journal of American studies

Special Issue: Media Agoras: Islamophobia and Inter/ Multimedial Dissensus

\title{
Islamophobia without Islamophobes: New Strategies of Representing Imperialist versus Suicide Terrorist Necropolitics in Homeland and Syriana
}

Mahmoud Arghavan

\section{OpenEdition}

\section{Journals}

\section{Electronic version}

URL: https://journals.openedition.org/ejas/16223

DOI: 10.4000/ejas.16223

ISSN: 1991-9336

Publisher

European Association for American Studies

\section{Electronic reference}

Mahmoud Arghavan, "Islamophobia without Islamophobes: New Strategies of Representing

Imperialist versus Suicide Terrorist Necropolitics in Homeland and Syriana", European journal of American studies [Online], 15-3 | 2020, Online since 29 September 2020, connection on 08 July 2021. URL: http://journals.openedition.org/ejas/16223 ; DOI: https://doi.org/10.4000/ejas.16223

This text was automatically generated on 8 July 2021

Creative Commons License 


\title{
Islamophobia without Islamophobes: New Strategies of Representing Imperialist versus Suicide Terrorist Necropolitics in Homeland and Syriana
}

\author{
Mahmoud Arghavan
}

\section{Introduction'}

1 Ever since the 9/11 terrorist attacks, the tropes of Islamist extremism, Islamic terrorism or terrorist Islamism, and suicidal violence have become pervasive in public discourses about global politics and Western governments' rhetoric of the "War on Terror." This is partly due to the numerous terror attacks, mostly suicidal, by militant Islamists around the world, with locations ranging from the U.S., France, England, and Germany to Turkey, Syria, Iraq, and Afghanistan. These suicide attacks have been generating worldwide fear, anger, and anxiety towards a militant Other who is equipped with an extremist ideology and a readiness to use their own body as a weapon to destroy the enemy. Yet, the equations of Islam with terror and Muslims with terrorists show the post-9/11 Islamophobic fruit of a longstanding Orientalist representation of "the rest" by the West and for the West. Perhaps old but still worth citing is Edward Said's classic definition of Orientalism "as the corporate institution for dealing with the Orient-dealing with it by making statements about it, authorizing views of it, describing it, by teaching it, settling it, ruling over it: in short, Orientalism as a Western style for dominating, restructuring, and having authority over the Orient" (Said 3).

2 Due to the Western media's strategy of what Said (1997) terms "covering Islam," Western publics seldom learn about the U.S.'s own history of neo-colonial interventions 
in the Greater Middle East and its cultivation of Islamic extremism in Afghanistan, implemented to contain and combat communism during the Cold War (Mamdani 119). Instead, media representations of "terror attacks" accompanied with Orientalist misrepresentations of Muslims and Islamicate cultures fortify Islamophobia around the world to produce "a cultural-ideological outlook that seeks to explain ills of the (global) social order by attributing them to Islam" (Semati 266). Consequently, Islamophobia is a "master discourse" that "conflates histories, politics, societies and cultures of the Middle East into a single unified and negative conception of Islam" (Semati 267) "as the civilizational foil of the west" (Beydoun 36). In American Islamophobia: Understanding the Roots and Rise of Fear (2018), Khaled Beydoun explains how Islamophobia was "not only endorsed and emboldened by law, but also carried out by government actors" (19). ${ }^{2}$ Therefore, one recurrent outcome of this outlook is that Islamophobes, either as private actors or policy makers in the West, presumptuously hold "Islamic faith and cultures" accountable for all "terrorist attacks," "suicide terrorism" and any other forms of extremist activities against the West and Western citizens.

3 Two representations of the figure of the suicide terrorist will be analyzed here as they are presented in the Showtime series Homeland (2011-) and the film Syriana (2005). This analysis pursues two goals. On the one hand, through studying these two cases, I will discuss the new representational mode concerning Arabs, Muslims and Middle Easterners in the American media in the post-9/11 era. In my analysis of Homeland and Syriana, I will examine "the simplified complex representational strategies" (Alsultany 14) that Evelyn Alsultany introduces in Arabs and Muslims in the Media: Race and Representation after 9/11 (2012). In her book, Alsultany scrutinizes the unprecedented "sympathetic portrayals of Arabs and Muslims" (4) in American media in the time of "mourning, fear, trauma, anger, and presumably justifiable racism against the entire Arab and Muslim population" subsequent to the September 11 terrorist attacks (1-2). Building on her argument, my aim is to explain that even though the Islamicate world and Muslims in the post-9/11 era have been portrayed more sympathetically, these media productions have had almost similar effects on the public to earlier Orientalist productions. As Alsultany elucidates:

These seemingly positive representations of Arabs and Muslims have helped to form a new kind of racism, one that projects antiracism and multiculturalism on the surface but simultaneously produces the logics and affects necessary to legitimize racist policies and practices. It is no longer the case that the Other is explicitly demonized to justify war or injustice. Now, the Other is portrayed sympathetically in order to project the United States as an enlightened country that has entered a postracial era. (Alsultany 16)

On the other hand, by discussing the figure of the suicide terrorist, I aim to counter the equation of "suicide terrorism" and Islam based on the logic of martyrdom as an exclusively Islamic way of destroying the enemy. Exploring the geopolitical context of emergence of "suicide terrorism" demonstrates that terrorism in its various forms has less to do with religious ideologies in general and with Islamic faith in particular and more to do with responding to imperial politics in British colonies and postcolonies, as well as U.S.-occupied territories in the Middle East, pre- and post-9/11. Nevertheless, the Islamophobic equation of Muslim and terrorist in the Western media, preceded by the Orientalist otherization of Arabs or Muslims, has been an important part of a process which Khaled Beydoun explains as "dialectical Islamophobia" (29). This process binds the private Islamophobia of ordinary people with the structural Islamophobia of 
the states such as in "War on Terror" policies enacted by Presidents George W. Bush, Barack Obama, and Donald Trump (Beydoun 29). In dialectical Islamophobia,

structural Islamophobia shapes, reshapes, and endorses views or attitudes about Islam and Muslim subjects inside and outside of America's borders. State actions legitimizes prevailing misconceptions, misrepresentations, and stereotypes of Islam and communicates damaging ideas through state-sponsored policy, programming, or rhetoric, which in turn emboldens private violence against Muslim (and perceived Muslims). (Beydoun 40)

The ultimate outcome of dialectical Islamophobia is legitimizing and valuing imperialist necropolitics while delegitimizing its opponent, namely the necropolitics of suicide terrorism. While Achille Mbembe (2003) defines necropolitics as the state's sovereign right to kill its citizens, the American imperialist necropolitics assumes a neo-colonial transnational right to kill beyond U.S. national borders.

\section{Necropolitics}

6 In defying Islamophobia and combating neo-colonial imperialist necropolitics, the agency of the colonized and the dominated is a critical and necessary means. By assuming the power of self-representation, Muslims could raise their authorial voices and present an authentic, not necessarily Islamophilic, image of Islam and Muslim societies. This is the main characteristic of Post-Orientalism where "a critically selfconscious colonial subject... attains agential autonomy by way of knowing the language of speaking (fighting) back to the sovereign [the Empire]" (xii), as Hamid Dabashi explains in Post-Orientalism: Knowledge and Power in Time of Terror (2009) in his efforts to bring Said's Orientalism up to date in the post-9/11 era. In the same vein, in Orientalism, Terrorism, Indigenism: South Asian Readings in Postcolonialism, Pavan Malreddy contends that Said's argument needs to be complemented by including subaltern resistance to colonial domination. Malreddy writes:

Said's overemphasis on 'synchronic essentialism,' that is, the distortion of the Orient in literary imagination and the ensuing attempts by the colonizers to transform the Orient in tune with such imagination suffer from inadequate attention to the resistance (which Said has later termed 'diachronic' instability (Said 2003 [1979]: 240) to the Orientalist discourse at large. (xxiii-xxiv)

7 Discussing the ways of resisting colonial rule and imperial powers in the colony and postcolony requires a differentiation between the types of powers used by the rulers in the colonies or postcolonies to dominate the occupied territories. In "Necropolitics" (2003), Achille Mbembe expands the ideas of Giorgio Agamben and Michel Foucault to explain the forms of subordination in the colonies. Mbembe argues that the notion of biopower is insufficient to account for the subjugation of life to the power of death in the colonies. He contends that the regime of biopolitical control in European societies is replaced with necropolitical control in the colonies because "the sovereign right to kill is not subject to any rule in the colonies. In the colonies, the sovereign might kill at any time or in any manner" (Mbembe 78). This means that in the colonies, the sovereign's right to 'kill and let live' or the threat of extralegal extrajudicial violence and death define the relations of power.

8 The necropolitical system of domination in our contemporary world creates what Mbembe calls "death-worlds," i.e., "new and unique forms of social existence in which vast populations are subjected to living conditions that confer upon them the status of 
the living dead" (Mbembe 92; emphasis in the original). Mbembe suggests that "today's form of necropower blurs the lines between resistance and suicide, sacrifice and redemption, martyrdom and freedom" (92). Stephen Morton explicates:

In the light of this argument, Mbembe's claim that death is a form of agency for people who live under colonial occupation helps to clarify the significance of violent, anti-colonial insurgency as an assertion of political sovereignty in the context of a colonial regime that defines politics in terms of the right to injure, torture and kill its subjects with impunity. (39)

From this perspective, the common stereotype of the Middle Eastern Muslim-born terrorist as well as the right extremists' equation of Islam with terrorism can be countered. In this vein, terrorism and suicide terrorism do not simply arise from a special religious faith, particularly Islam, but are byproducts of colonial domination and occupation of the Muslim world. To begin with, an intersectional study of the historical roots of the American Orientalist cultural and political imaginary, U.S. imperialist geopolitics in the Middle East and the American neocolonial 'war machine' in Afghanistan could shed light on the complex history of the rise of Islamic extremism and divert from the prevalent equation of Islam and terrorism employed today. In "Good Muslim, Bad Muslim," Mahmood Mamdani elucidates that during the Cold War and "after the defeat in Vietnam and the Watergate scandal, at the start of Reagan's second term, the United States decided to harness, and even to cultivate, terrorism in the struggle against regimes it considered pro-Soviet" (Mamdani 769). As a result, Mamdani explains, "the tradition of jihad-of a just war with a religious sanction, nonexistent in the last 400 years-[was] revived with U.S. help in the 1980s" (770). The jihad against communism and the Soviet Union's occupation of Afghanistan continued after the Soviets retreated in 1989, thereby triggering a long civil war in Afghanistan. This led to millions of casualties, the mass displacement of four million more Afghans and the destruction of Afghanistan's infrastructures. Later on, the Taliban and its "suicide terrorism" emerged out of the agonies and despair of war against the Soviet Union and the subsequent civil war, which had turned some regions of Afghanistan into a death-world where people were being reduced to the state of living dead. Under these circumstances, "suicide terrorism" might become the last chance of expressing agency for somebody who is already in a state of living dead.

At this point, it needs to be iterated that this paper does not in any way aim to either justify "suicide terrorism" or celebrate terrorists as "freedom fighters." Rather, it proposes to view terrorism in light of anti-colonial insurgencies and resistance to colonial occupation.

\section{Representation of Suicide Terrorism}

After a long history of Orientalist depictions of Muslims and Islam in Hollywood which is well documented by Jack Shaheen's Reel Bad Arabs: How Hollywood Vilifies a People (2003), in recent years, Hollywood and Western Media have begun to offer a more differentiated and sympathetic image of Arabs and Muslims. At first glance, the new balanced portrayals of Arabs and Muslims can be interpreted and appreciated as a decline in Islamophobic sentiments around the world (or at least among Hollywood producers). The recent parliamentary elections in Europe and the latest presidential election in the U.S., however, refute this optimistic turn. On the contrary, it seems that a quiet Islamophobia is on the rise: even though more people are avoiding making 
Islamophobic/xenophobic statements in public, the Islamophobic voters in Europe and the U.S. are quietly voicing their opinions at the polls. Recent media productions and Hollywood films are just mirroring this transformation from overt to covert Islamophobia. Alsultany reminds us that as the U.S. government's overt propaganda of war in the days and weeks following $9 / 11$ became gradually less effective and more controversial, "the production and circulation of 'positive' representations of the 'enemy' has become essential to projecting the United States as benevolent, especially in its declaration of war and passage of racist policies" (7). This policy was to promote the delusion of entering a multicultural and postrace era, but in reality, it declared the formation of "a new postrace racism" (Alsultany 7). Thus, a new critical analysis of sympathetically portrayed Arabs and Muslims in the context of their narratives will reveal these ideological messages in relation to the larger discourse of the "War on Terror" and also point out how these portrayals contribute to the illusion of a multicultural post-race era.

On another front, one needs to bear in mind that Islamophobia is not solely propagated by the right-wing press and politicians. Khaled Beydoun reminds us that "[c]ontrary to popular caricatures and flat media portrayals, Islamophobes are not always conservatives, far-right zealots, 'lone wolf' killers, presidential hopefuls-or presidents -using hateful rhetoric, evangelical ideologues, or Trump voters" (30). In the same vein, Hamid Dabashi writes in "The Liberal Roots of Islamophobia" (2017) that liberal Islamophobes like Bill Maher, who in HBO's "Real Time with Bill Maher" referred to the Qur'an as "Islam's hate-filled holy book," "are finagling their hatred of Muslims with smiling faces, silly jokes, phony arguments, forced laughter and manufactured consent -with the full cooperation of otherwise perfectly respectable outlets." Dabashi contends that "Islamophilia is as deranged as Islamophobia," and that these critics "dare to talk about the 'battle of ideas' without a single citation of any living or dead Muslim theologian, philosopher, mystic, poet, artist, or public intellectual evident in their vertiginously vacuous prose" (Dabashi).

Deepa Kumar in Islamophobia: The Cultural Logic of Empire reasons that although neoconservatives and the realist/liberal camps constitute two different modes of thought in policy circles with divergent rhetoric and strategies, "they share a common commitment to U.S. imperialism. Their points of contention revolve around the best ways to maintain U.S. dominance and global hegemony" (5). She contends that immediately after $9 / 11$, neo-conservative and liberal Islamophobes came together to converge domestic and foreign policy to wage the "War on Terror." Kumar maintains that this resulted in "the construction of the overarching 'Islamic terrorist' enemy that must be fought abroad and at home. The corresponding 'green scare' (green is the color of Islam) is similar to the various anticommunist 'red scares' that marked US domestic politics in the twentieth century" (5). Therefore, detecting the latent Islamophobia of liberals and leftists or the implied Islamophobic messages conveyed along with sympathetic portrayals of Arabs and Muslims in Hollywood films and TV shows in the prolonged "War on Terror" era is a task that must be taken on.

Hollywood's new representational strategies, with regard to Islam and the Middle East, as Alsultany contends, include "Inserting Patriotic Arab or Muslim Americans," "Sympathizing with the Plight of Arab and Muslim," "Challenging the Arab/Muslim Conflation with Diverse Muslim Identities," "Flipping the Enemy," "Humanizing the Terrorist," "Projecting a Multicultural U.S. Society," and "Fictionalizing the Middle 
Eastern or Muslim Country" (21-26). These strategies assist the producers to exonerate themselves from charges such as Islamophobia and Orientalism in the so-called postrace era, ${ }^{3}$ while simultaneously allowing them to produce films and shows that cater to the public's Islamophobic and Orientalist impulses.

I chose to study Homeland and Syriana for two reasons. On the one hand, the figure of the suicide terrorist is represented in both. On the other hand, they both attempt to complicate and challenge former stereotypical portrayals of Middle Easterners and Muslims. The writers of Homeland and Syriana have tried to shift away from Islamophobia and negative stereotyping of Muslims and Arabs. They position their viewers to either largely sympathize with the plight of Muslims or show antipathies towards the U.S. imperialist politics in the Middle East, ultimately presenting viewers with some explanations for George W. Bush's enquiry of "Why do they hate us?" However, the Islamophobic messages of Samuel P. Huntington's Clash of Civilizations (1996) between the West and Islam in the form of a war between CIA agents or U.S. marines and Islamic extremists is still at play. Therefore, despite avoiding a monolithic picture of Islam, Arab and Muslim identities are still understood and evaluated primarily in relation to terrorism and sometimes as suicide assailants. Either they areto use Mahmood Mamdani's concept-Good Muslims in alliance with the U.S. in fighting the "War on Terror" or they are Bad Muslims who plot a terror attack against the West.

\section{Homeland}

The first two seasons of the Showtime series Homeland, which was renewed for a seventh season in 2019, revolves around sergeant Nicholas Brody (Damian Lewis), an American marine veteran who had been captured by $\mathrm{Al}$-Qaeda in Iraq and spent eight years of his life in Abu-Nazir's (Navid Negahban) custody. After a long term of torture, humiliation and darkness, he was assigned to teach English to Nazir's son Issa (Rohan Chand) in return for more comfort. Nazir's son is killed along with eighty-one other schoolchildren in a drone attack which was planned by the American army to assassinate Abu-Nazir. The Vice President (Jamey Sheridan) authorized bombing the school next to Nazir's house, even though he knew that this attack would affect schoolchildren. Later, in a press conference, he negates the whole incident and calls it media propaganda. Under the influence of Abu-Nazir, Brody converts to Islam, becomes Nazir's disciple and swears to avenge Issa's death. During an American forces operation in Iraq, Brody is freed from an Al-Qaeda jail and returned to the U.S. as a war hero. After passing a difficult period of readjustment to his family and old life, Brody receives the mission and necessary equipment to execute a suicide attack against the Vice President of the United States, who is going to announce his candidacy for the presidency. However, a phone call from his daughter at the last second stops him from detonating his bomb vest.

17 Aside from Brody and his family, the other two main characters of Homeland, Carrie Mathison (Claire Danes) and Saul Berenson (Mandy Patinkin), are also white Americans. The main antagonist in the narrative is an Al-Qaeda leader from Iraq. Although this setting appears to tell another American classic good-versus-evil story with all its potentials for misrepresentation of the Muslim evil, the narrative complicates portrayals of Muslims and terrorists and avoids the usual stereotypical imagery. Carrie and Saul are two CIA agents whose heroic acts always neutralize terrorist plots and 
save American lives. The CIA director, David Estes (David Harewood), is played by an African American and his role is designed to project the multiculturalism and meritocracy of American society. Although David's character fulfills the diversity agenda of "neoliberal multiculturalism," his mishandling of critical situations perpetuates the viewers' belief that perhaps saviors ought to be white Americans. The audience could also "sympathize with the plight of Arabs and Muslims" (Asultany 22) through witnessing the innocent killing of Issa along with the other schoolchildren by a CIA-sanctioned drone strike. At the same time, Abu-Nazir is not portrayed as an absolute devil, rather as a charismatic intelligent leader. He is also "humanized" (Alsultany 24) as a loving father who is not plotting the terror attack against American civilians purely because of his Islamist cause, but because he wants to take revenge on the responsible person for his son's killing.

Abu-Nazir could easily have the Vice President assassinated by his other American disciple, Tom Walker (Chris Chalk), who was captured and converted to Islam in Iraq along with Brody. Yet, he plots a suicide attack on American soil and convinces Brody to implement this mission. A suicide terror attack by a white American would demonstrate the power of an Islamic ideology that can capture the soul and body of an American war hero and inspire him to sacrifice his life in order to coerce the American military to withdraw from occupied territories in the Middle East. As a part of the tradition of the suicide bombers, Sergeant Brody tapes a statement before the operation, where he explains the motivation for his action:

I love my country, what I am is a marine like my father before me and his father before him. And as a marine, I swore an oath to defend the United States of America against enemies both foreign and domestic. My action this day is against such domestic enemies-the vice president and members of his national security team, who I know to be liars and war criminals, responsible for atrocities they were never held accountable for. This is about justice for eighty-two children, whose deaths were never acknowledged and whose murder is a stain on the soul of this nation.

19 However, it is against the politics of the American media industry to portray a white American (even one that converted to Islam) as a terrorist, let alone a suicide bomber. The story is not told because terrorists always originate in the Orient and "the land of the free" is by definition destined to cultivate freedom and democracy, not to breed terrorism. According to American mainstream media, only Arab Muslims or Muslims from the Middle East can give up all worldly ties and sacrifice their lives in order to kill the enemy who is threatening their community.

Brody, who had once disappointed Abu-Nazir, proves his loyalty to him by killing Tom Walker. He progresses to be elected to the United States House of Representatives. Nonetheless, Brody's alliance with Abu-Nazir continues in the second season of Homeland. While Carrie and Saul are leading an operation to assassinate Abu-Nazir in Beirut, Brody saves Nazir's life at the last minute by warning him about the operation. Among the documents that Carrie collects from the field in Beirut, Saul finds Brody's taped testimony to his unfulfilled suicide attack. Under interrogation Brody confesses to his cooperation with Abu-Nazir and pledges to work as a double agent for the CIA to deter terror attacks on America. At the end of the second season, a car-bombing hits the CIA headquarters leaving several casualties including David, the CIA director. Because Brody's car has been used for the explosion, the evidence seems to confirm that Brody had conducted the terror attack. However, Carrie, who suffers from bipolar disorder and is genuinely dedicated to protecting U.S. national security, represents the 
Manichean spirit of the discourse of the "War on Terror": ${ }^{4}$ she believes that Brody is innocent and helps him to flee to Canada. Brody comes back in the third season of the show to prove his patriotism by penetrating the Iranian Intelligent Service inside Iran. After his arrest in Iran, he is hanged by the Iranian Revolutionary Guard in a dramatically depicted Iranophobic scene. Brody's public execution in a residential neighborhood in Tehran before the Iranian public (including children) who are chanting "Death to America" and "Allah-o Akbar," links Islamophobia and Iranophobia conveniently at a time when a conflation of Middle Easterners, anti-American Muslims, and terrorism was needed more than ever. It was a time when U.S. propaganda was aimed at orchestrating an international coalition against Iran and its controversial nuclear program. This narrative introduced the Islamic Republic of Iran, equipped with nuclear weapons, as a larger threat to global peace and regional stability than Al-Qaeda and Saddam ever could be.

21 Homeland represents the anti-American threat of Islamist terrorism as an everincreasing menace within the U.S. borders and against the U.S. forces and allies in the Middle East. The Islamist terrorists are represented as cunning enemies of the West, but Carrie and Saul will always overcome the challenges of neutralizing their plots.

\section{Syriana}

Syriana, ${ }^{5}$ directed by Stephen Gaghan and released in 2005 (two years after the U.S. military invasion of Iraq) offers an overview of U.S. imperialist geopolitics in the Middle East and its consequences for the marginalized Muslim individuals and communities in the region. With sympathetic portrayals of Arab Muslims and other Muslims such as Pakistanis, the film holds global capitalism and American imperialism accountable for the plight of some groups of Muslim migrant laborers in the oil states of the Persian Gulf.

Wasim and his father, Saleem Ahmed Khan (Mazhar Munir and Shahid Ahmed), two Pakistani migrant workers at a Connex refinery, are being laid off due to a Chinese company outbidding Connex for the rights to run that facility. Unemployed and threatened by deportation and poverty, Wasim desperately and unsuccessfully searches for work. Wasim and his friend join an Islamic school to learn Arabic to improve their employment prospects. Then they meet a charismatic Islamic fundamentalist cleric who earlier had stolen an anti-tank missile from a CIA agent. The teachings of the radical teacher of the Madressa triggers Wasim's personal incentive to take revenge on the cause of his plight. A radical interpretation of his religious faith equips him with an ideology to conduct an act of suicide terrorism. Eventually, divested of their political status, the two Pakistani workers take refuge in an extremist ideology to sacrifice their "bare lives" in a suicide attack by riding their weaponized vessel into on a ConnexKillen LNG tanker. Wasim represents the people of the extremely poor regions of the global south as being the most vulnerable to extremist ideologies. These suicidal assailants with their stateless bodies symbolize that if "capitalism cannot exist without waste [i.e. the victims of global capitalism]," as one economic advisor in the film tells us, these victims, who had been reduced to a state of living dead, will come back and combat the capitalist system. Global neoliberalism degrades Wasim from an individual citizen of the world into a stateless, "homeless" non-citizen worker of global capitalism. In Agamben's terminology Wasim had been transformed from "Bio" into 
"Zoe" (see Agamben 1998), without any political rights. Wasim is the last part of a network of arms trafficking and proxy wars in the Middle East including Iranian intelligence agents, Hezbollah, CIA and Islamic clerics both in Lebanon and in the religious schools. Captured by Islamist ideology, Wasim and his friend arm their bare bodies $^{6}$ with a missile that was very likely produced by the American weapons industry to conduct a suicide attack on one of the economic arms of the American war machine. According to Achille Mbembe,

A war machine combines a plurality of functions. It has the features of a political organization and a mercantile company. It operates through capture and depredations and can even coin its own money. In order to fuel the extraction and export of natural resources located in the territory they control, war machines forge direct connections with transnational networks. (32)

Syriana's narrative exposes the U.S. war machine and its rationale very critically. In a parallel plot, the CIA assassinates Prince Nasir (Alexander Siddig), who in contrast to his father's repressive government and conformism to American interests, is a progressive politician dedicated to a nationalist agenda. Prince Nasir is going to foster long-term sustainable development by introducing democratic reforms and diversifying the economy of his country in preparation for the time when the oil runs out. As the emirate's foreign minister, Prince Nasir grants natural gas drilling rights to a Chinese company, which greatly upsets the U.S. oil industry and the U.S. government. Thus, the American government urges the King to name his younger son Meshal (Akbar Kurtha) as his successor, causing Nasir to attempt a coup. On his way to assume power as the new king with a convoy of his supporters, the CIA strikes the automobile of Nasir and his family with a guided bomb from a circling predator drone, killing them instantly. The fact that the U.S. feels free to assassinate foreign leaders on their own soil is evidence of its imperialist necropolitics which I would term as the "neocolonial transnational right to kill."

\section{Suicide Terrorism in the New Discourse on Terrorism}

Scrutinizing the history of suicide terrorism and representations of this phenomenon in the new discourse on terrorism will help us to better understand why the two characters who were on suicide missions, Brody in Homeland and Wasim in Syriana, act differently in the end. How can we make logical sense of the representations of suicide terrorism in the narratives of Homeland and Syriana, where a white American does not fulfill his suicide terrorist mission, but a young Muslim man from Pakistan accomplishes his assigned task?

In the post-Cold War era and the post-9/11 era of the "War on Terror," Islam has come to represent the horror of terrorism and suicide terrorism and this has subsequently been specialized for Muslims. However, studies on the history of suicide terrorism can disrupt the equivalence of Islam and terrorism by bringing into light the existence of Jewish terrorists in $66 \mathrm{AD}$, Christian terrorism, and Shi'a Islamic terrorism of Islamili Assassins. In Dying to Win: The Strategic Logic of Suicide Terrorism (2006), Robert A. Pape shows that religion is "rarely the root cause of terrorism [but] often used as a tool in recruiting and in other efforts in service of the broader strategic objective" (4). Pape defines terrorism as "the use of violence by an organization other than a national 
government to intimidate or frighten a target audience.... In general, terrorism has two broad purposes: to gain supporters and to coerce opponents" (9). According to him, the most important forms of terrorism include "demonstrative," "destructive," and "suicide" terrorism. Pape writes:

'Demonstrative terrorism' is as much political theater as violence. It is directed mainly at gaining publicity, for any or all of three reasons: to recruit more activists; to gain attention to grievances from soft-liners on the other side; and to gain attention from third parties who might exert pressure on the other side. (9)

"Destructive terrorism," on the contrary, "is more aggressive, seeking to coerce opponents with the threat of injury or death as well as to mobilize support for the cause" (Pape 10). The most aggressive form of terrorism is, however, "suicide terrorism." According to Pape, "[w]hat distinguishes a suicide terrorist is that the attacker does not expect to survive the mission and often employs a method of attack (such as a car bomb, suicide vest, or ramming an airplane into a building) that requires his or her death in order to succeed" (10). Nearly all suicide terrorists pursue a secular and strategic goal of either coercing the occupying powers to withdraw from their homeland or compelling a target government to change policy. According to Pape "suicide terrorism attempts to inflict pain on the opposing society to overwhelm its interest in resisting the terrorists' demands, and so to induce the government to concede, or the population to revolt against the government" (27-8). Because militarily they are in a weaker position in the power structure, they sacrifice their own lives to cause the colonizer or its agents damage in the most efficient manner. Velupillai Prabhakaran, the leader of the communist Liberation Tigers of Tamil Eelam (LTTE or the Tamil Tigers) in Sri Lanka, in a major speech in 1998 said:

In terms of manpower, firepower and resources, the enemy was strong and the balance of military power was in his favor. Yet we had an extraordinary weapon which was not in the arsenal of the enemy. The courage and commitment of our fighters was our most powerful weapon in the battle.... The Black Tigers [suicide squad] are the self-protective armor of our race. They are the men of flame who can destroy the enemy's armed strength. (in Pape 33)

Alex Houen in "Sacrificial Militancy and the Wars around Terror" reminds us that "the first suicide bombings in the early twentieth century were carried out by secular Russian anarchists, and the next major instance was that of Japanese 'kamikaze' pilots in World War II" (114). Although no religion inherently promotes and justifies terrorist acts or suicide terrorism, under certain circumstances religion can be instrumentalized by political actors and religious leaders involved in games of coercion to "institute an idealism of transcendent justifications for a community" (Houen 115). These transcendent values could be "democracy," "freedom," or "God," and "the nation" (Houen 114).

Yet, in the contemporary era, except for the communist Liberation Tigers of Tamil Eelam in Sri Lanka, most suicide attacks around the world have been perpetrated by radical Islamist organizations such as Hamas in Lebanon, the Palestine Islamic Jihad, AlQaeda and finally ISIS (see Pape passim). The Islamic background of the majority of twenty-first-century terrorists, the religious rhetoric of the mobilizing forces of the terrorist activities stated in the sermons of some radical Islamists and reflected in instructions for terrorist operations, can provide convincing evidence for Islamophobes who identify Islam with terrorism. 

Laden and others reads:

The ruling to kill the Americans and their allies-civilians and military-is an individual duty for every Muslim who can do it in any country in which it is possible to do it, in order to liberate the al-Aksa Mosque and the holy mosque [Mecca] from their grip, and in order for their armies to move out of all the lands of Islam, defeated and unable to threaten any Muslim. (in Pape 32)

The text of the operative instructions and spiritual guidelines for the terrorists who committed the attacks of September 11, 2001 reads:

Read the Al-Tawbah [i.e., Repentance], the Anfal chapters [in the Qur'an], and reflect on their meaning and what Allah has prepared for the believers and the martyrs in paradise.... Be cheerful for you have only moments between you and your eternity, after which a happy and satisfying life begins, the eternal pleasures with the prophets, the righteous, the good and the martyrs, ... Allah is our best Representative and Defender. 'That devil scares his followers' who admire Western civilization and swallow their love and beatification of it with cold water... 'God will frustrate conspiracies of the infidels.' Do not take revenge for yourself, but make your strikes and everything in the name of Allah.... When the time of truth and the Zero Hour arrives, then rip open your clothes, and bare your chest to embrace death for the sake of Allah! [. . .] 'Do not consider those who were killed for the sake of Allah dead,' ... and your last words should be: .There is no god but Allah. Mohammed is His messenger!' ("The Last Night Letter")

Three identical copies of this manifesto hand-written in Arabic were recovered from the hijackers' belongings in Boston, Washington DC and at the crash site of United Airlines Flight 93 in Western Pennsylvania. The FBI released this evidence on September 28, 2001 and named it "The Last Night Letter." It has been also known as "Manual for a Raid." Multiple references in this document to some selected passages from the Qur'an and the history of Islam to justify martyrdom and mass murder of enemies of Islam have be utilized by conservatives to prove the accuracy of the 'clash of civilizations' theory and to legitimize rising Islamophobic sentiments.

Nevertheless, Mbembe's notions of necropower and necropolitics explain suicide terrorism as expressions of agency and sovereignty over life, i.e., death and afterlife for the colonized subject who has been already stripped to his/her bones of his/her agency by the colonizers. In this way, the religiously stimulated "martyr-to-be" sacrifices his/ her own life and body for two higher ends. On the one hand, martyrdom "paves the way to a happy life" which "[he/she] believes, rests only in God himself. And only through conversion can an authentic relationship to God arise" (Mbembe 50). On the other hand, the suicide terrorist's commitment to martyrdom struggles to coerce the occupying powers and colonizers to withdraw from their homeland, which will hypothetically facilitate the happiness of his/her people. Thus, the language of the instructions for the suicide terrorists of the September 11 and other manuals can be explained as formulation of a religious necropolitics. to elucidate the relation between terror, sacrifice and freedom. Mbembe writes that Heidegger's granting an existential status to the human "being toward death" as the "the decisive condition of all true human freedom" (Heidegger 74) means "one is free to live one's own life only because one is free to die one's own death" (Mbembe 90).

Georges Bataille in an essay on "Hegel, Death and Sacrifice" writes, "in order for man to reveal himself ultimately to himself, he would have to die, but he would have to do it 
while living-watching himself ceasing to be. In other words, death itself would have to become self-consciousness of itself" (19). Thus, "the human subject has to be fully alive at the very moment of dying, to be aware of his own death, to live with the impression of actually dying" (Mbembe 90). In this sense, sacrifice achieves the condition of selfawareness of death at the very moment of ceasing to exist. The sacrificed "dies seeing himself die, and even, in some sense, through his own will, at one with the weapon of sacrifice" (Mbembe 90). In the case of suicide bombers,

the sacrifice consists of the spectacular putting to death of the self, of becoming his or her own victim (self-sacrifice). The self-sacrificed proceeds to take power over his or her death and to approach it head on. This power may be derived from the belief that the destruction of one's own body does not affect the continuity of the being. The idea is that the being exists outside of us. The self-sacrifice consists, here, in the removal of a twofold prohibition: that of self-immolation (suicide) and that of murder. (Mbembe 38)

Martyrdom embodies "being-towards-death." It can be a religious act, as in the case of Jihadi suicide bombers, or motivated by secular imperatives, as with the freedom fighters in the colony or the soldiers of the colonizing powers who are called rhetorically to sacrifice their lives for the higher values of the nation such as freedom and democracy, ${ }^{8}$ but practically for the interest of the Empire. The martyrs continue to live because if their deaths were religiously inspired, religion had equipped them with afterlife philosophy. If their deaths had secular motivations such as independence and liberty for the colonized "freedom fighters" or protecting freedom and democracy for the fighters of the "War on Terror," the martyrs continue to thrive through their ideals and historical deeds.

The new discourse on terrorism, descending from Orientalism, essentializes this religious necropolitics as inherently Islamic to serve the interests of Empire and justify the suspension of the rule of law in occupied territories such as Iraq and Afghanistan. As Edward Said writes in "The Essential Terrorist," an article published in Blaming the Victims: Spurious Scholarship and the Palestinian Question (1988), "the spurious excuse of 'fighting terrorism' serves to legitimize every case of torture, illegal detention, demolition of houses, expropriation of land, murder, collective punishment, deportation, censorship, closure of schools and universities" (Said 156).

In another essay entitled "Punishment by Detail" (2002), Said criticized the distorted image of the reality of Palestinian people through the misrepresentation of Palestinian suicide bombings. While admitting the unforgivable horror of terrorism, he points out that: "Suicide bombing is reprehensible but it is a direct and, in my opinion, a consciously programmed result of years of abuse, powerlessness, and despair. It has as little to do with the Arab or Muslim supposed propensity for violence as the man in the moon." Stephen Morton explains that Said criticizes the discourse of terrorism because it "is used by the United States and its allies to describe violent acts of resistance to imperial occupation rather than addressing the violence of imperial occupation itself" (36). Morton argues that the causal logic of the discourse on terrorism "conceals the fact that the threat of terrorism is an instance of metalepsis: an effect of colonial discourse that is presented as a cause" (36). This logic, according to him, focuses "on the emotional and aesthetic connotation of terror instead of examining the geopolitical context of its production" (Morton 37). Similarly, Malreddy (2015) writes that the term "terrorism" "has come to represent a nameless Oriental collective that stretches from the Saharan Tuareg in North Africa to the Solomon Islands in the Asia Pacific. Thus, ... 
the Oriental collective that is glutted by seamlessly borderless terrorists can no longer be defined in terms of a fixed geographical entity" (3). Indeed, the new discourse on terrorism designates terror to alien domains and outlines the borders of the Orient according to the terrorists' origins. In other words, Orientalism defined the Orient as geography of Otherness which is characterized by Islamic fundamentalism, women's repression and tyrant rulers. The Orient for the new discourse on terrorism constitutes an imaginary geography from which the terrorists come. "Terrorism" defines where the Orient is, because "[t]error and torture always refer to the actions of others, never to ourselves [meaning Americans]" (Gregory 229). Moreover, the United States of America is by definition incapable of breeding terrorists and/or equipping them with the required ideological weapons. Even in case of Muslim American citizens involved in terrorist attacks in the U.S., their country of origin outside of U.S. borders, somewhere in the Orient, will be pronounced as their homeland because "home-grown terrorism" in the West is unimaginable. Therefore, a terrorist is always already "foreign-grown" (Malreddy 4). As a result, even in the cases of Timothy McVeigh ${ }^{10}$ and Andres Behring Breivik ${ }^{11}$, the term "home-grown terrorist" has been hardly used. Malreddy reports, "four years after the tragedy, Breivik is certified as a 'maverick,' a 'nut-ball,' a 'crazyloner'-but not quite a terrorist" (4).

Malreddy writes that "unlike 'old' terrorism, which is defined as a violent but unlawful form of political resistance, 'new' or 'categorical terrorism' refers to the nonconventional, nonpolitical, and even 'irrational' ${ }^{12}$ violence that primarily targets Western civilians" (Goodwin in Malreddy 4). Thus, in the new discourse on terrorism

[i]f a Westerner kills his fellow civilians, he is a 'crazy-loner;' if an Oriental kills his fellow civilians, he is the good old terrorist; and if the same Oriental kills Western civilians, he is the 'new' terrorist. Only Western ways of killing civilians-be it through war, invasion, or military conquest [which Mbembe explains, are not 'subject to legal and institutional rules' (Mbembe 78)]-are deemed superior, proper, and unquestionably legitimate. (Porter in Malreddy 4)

Therefore, according to the logic of the new discourse on terrorism, Sergeant Brody could not be portrayed as a suicide bomber because this role is reserved for Muslim Middle Easterners such as Wasim.

\section{Conclusion}

As Achille Mbembe (2003) reminds us, an important feature of the wars of the globalization era is that "military operations and the exercise of the right to kill are no longer the sole monopoly of states, and the 'regular army' is no longer the unique modality of carrying out these functions" (31). The growing gap between high-tech and low-tech means of war in addition to the illegitimate imperialist presence of the West has given rise to the necropower of the figure of the 'suicide terrorist' who uses his/her own body as a means to confront the state's necropower. Therefore, from a broader view, the "War on Terror" and terrorist suicide attacks represent an ongoing contest between the U.S.-led Western states and non-state militant Islamist organizations over the "right to kill" the Other who is either, for Americans, a threat to national security and democracy or, for Al-Qaeda followers and ISIS fighters, a threat to their Islamist ideology and the cause of the plight of destitute Muslims and Arabs in the Middle East. After all, G.W. Bush's "War on Terror" agenda was based on his assumed sovereign 
right to kill the adversaries of what his administration framed as modern liberal democracy.

On another level, the Muslim people of the Middle East are subject to both U.S. neocolonial necropolitics and imperialist biopolitics. These people, who are full citizens in their countries of origin during and after the state of exception, will either be killed in the middle of the bloody competition between the U.S. necropolitics and the necropolitics of violent non-state actors such as Al-Qaeda, Taliban and ISIS or flee their lands in order to survive. As a result, displacement divests these war refugees, who are often educated and skilled workers in their homelands, of their human rights to a happy and safe life and alters them from full citizens of their countries to stateless asylum seekers and eventually to second-class cheap labor force for Western countries. In this way, Empire exports products of its arms industry to the flourishing markets of the war zones and imports cheap labor. This simultaneity of biopolitics and necropolitics is the unique characteristic of a neocolonial imperialist power in the twenty-first century, which under the state of exception assumes the right to kill, to allow to live, or to expose to death, which eventually manipulates the natural flow of the world populations in many directions and many respects.

The American neo-colonial necropolitics could not be executed in the Middle East without an Islamophobic construction of an "Arab-Middle-Eastern-Muslim Other." In Islamophobia and Racism in America (2017), Erik Love explains that the racialization of Muslim identity in the "War on Terror" prescribed Muslim Americans and nationals of Muslim majority countries a collective political identity which would translate into the suspicion of terrorism and subversion. Islamophobia, according to Semati, "posits 'Islam' as a conception of the world that is incompatible with modernity, with civilization, and, more important, with Euro-Americanness. Islamophobia, on the one hand, creates difference (the 'Other') and, on the other hand, erases difference (all of 'them' are the 'same')" (267). Therefore, American imperialism instrumentalizes modernity and its values such as freedom, human rights, democracy, women's rights and equality to racialize Islam, otherize Muslims, and implement politics which target those states and non-governmental organizations who endanger its capitalist interests.

Because modern racism based on biological differences has been long discredited and disgraced, Islamophobia, as "an essentialist view of peoples whose culture it deems 'different' in an eternal, fixed, and immutable fashion" (Semati 266), is built on cultural differences. Semati points out that "[i]n the 'neo-racist' logic, the Other/self dichotomy is no longer explained in an inferior/superior framework. Instead, the Other is believed to be "different"' (266). In the era of neo-liberal multiculturalism which largely translates into "racism without races," "cultural racism" (Balibar, Naber) substitutes race and "racial difference" with culture and "cultural difference." It also replaces insults against Muslims such as "sand nigger" and "diaperhead" with respectful sentences such as "they are different" and "we cannot mingle because our life-styles and traditions are incompatible." Aside from the "cultural racism" of private Islamophobes, according to Nadine Naber in "Look, Mohammed the Terrorist Is Coming!" the period of post-9/11 has witnessed a "nation-based racism" of structural Islamophobia as well. According to Naber, '[i]n the context of the 'War on Terror,' the interplay between culture-based racism and nation-based racism has articulated subjects perceived to be 'Arab/Middle Eastern/Muslim' not only as a moral, cultural, and civilizational threat to the 'American' nation, but also as a security threat" (280). 
Beydoun (2018) shows that structural Islamophobia reflects and authorizes the private Islamophobia of ordinary people on the one hand, while it is supported, voted for and reelected by private Islamophobes and reproduced and reinstated by the media, art and literature, on the other hand.

As Alsultany contends, "government and media discourses" on the "War on Terror" are inextricably interrelated and together form a "hegemonic field of meaning" premised on "they hate us for our freedom" (Arabs and Muslims 7). This discourse "provided the logic and justification needed to pass racist foreign and domestic policies and provided the suspicion needed for many citizens to tolerate the targeting of Arabs and Muslims, often without any evidence that they were involved in terrorist activities" (Alsultany 7). Alsultany, in response to a conservative film critic who was concerned that humanizing the terrorists in films such as Syriana blurred the moral difference between terrorist and those who fight terrorism and raised sympathy for the terrorists, points out that "viewer responses suggest that for most the dominant message remains the same: the United States is at war against terrorism because Arabs and Muslims are a threat" (38). She views the impact of these "simplified complex representational strategies" (14) to being limited to circumventing accusations of racism for the writers and producers with the aim of maintaining the largest viewership possible. These viewers generally "take away the message that Arabs and Muslims are a threat to U.S. national security despite a few Arab and Muslim characters that are against terrorism" (Alsultany 38).

What Hollywood films and American TV shows have failed to convey to their viewers is that there are some millions of Muslims who are living peacefully in the U.S. just like other citizens and work as doctors, engineers, university professors, taxi drivers, construction workers, etc. whose stories and characters, regardless of their religious views, could be told and depicted in American films and TV shows, and not just relegated to stories related to terrorism and war in the Middle East.

\section{BIBLIOGRAPHY}

Agamben, Giorgio. Homo Sacer: Sovereign Power and Bare Life. Translated by Daniel Heller-Roazen, Stanford UP, 1998.

Alsultany, Evelyn "Arabs and Muslims in the Media after 9/11: Representational Strategies for a 'Postrace' Era.” American Quarterly, vol. 65, no. 1, 2013, pp. 161-169.

---. Arabs and Muslims in the Media: Race and Representation after 9/11. New York UP, 2012.

Balibar, Etienne. “Is There a 'Neo-Racism'?” Race, Nation, Class: Ambiguous Identity, edited by Etienne Balibar and Immanuel Wallerstein, Verso, 1991, pp. 17-28.

Bataille, Georges. "Hegel, Death and Sacrifice." Yale French Studies, vol. 7, no. 8, 1990, pp. 9-28.

Beydoun, Khaled A. American Islamophobia: Understanding the Roots and Rise of Fear. Tantor Media, 2018. 
---. "Islamophobia: Toward a Legal Definition and Framework." Columbia Law Review Online, no. 116, 2016, March 2020. Accessed 15 September 2020. https://columbialawreview.org/content/ islamophobia-toward-a-legal-definition-and-framework/.

Bonilla-Silva, Eduardo. Racism without Racists: Color-blind Racism and the Persistence of Racial Inequality in the United States. Rowman \& Littlefield, 2003.

Dabashi, Hamid. “The Liberal Roots of Islamophobia." Al-Jazeera, March 2017. Accessed 4 September 2020. https://www.aljazeera.com/indepth/opinion/2017/03/liberal-rootsislamophobia-170302152226572.html.

---. Post-Orientalism: Knowledge and Power in Time of Terror. Transaction Publishers, 2009.

Homeland. Created by Alex Gansa and Howard Gordon, Showtime Networks, 2011-2019.

Houen, Alex. "Sacrificial Militancy and the Wars around Terror." Terror and the Postcolonial, edited by Elleke Boehmer and Stephen Morton, Wiley Blackwell, 2015, pp. 113-140.

Kumar, Deepa. Islamophobia: The Cultural Logic of Empire. Haymarket, 2012.

Love, Erik. Islamophobia and Racism in America. New York UP, 2017.

Makiya, Kanan, and Havan Mneimneh. "Manual for a 'Raid'." Striking Terror: America's New War, edited by Robert B. Silvers and Barbara Epstein, New York Review of Books, 2002, pp. 319-27.

Malreddy, Pavan K. Orientalism, Terrorism, Indigenism: South Asian Readings in Postcolonialism. SAGE, 2015.

Mamdani, Mahmood. Good Muslim, Bad Muslim: America, the Cold War, and the Roots of Terror. Doubleday, 2004.

---. "Good Muslim, Bad Muslim: A Political Perspective on Culture and Terrorism." American Anthropologist, vol. 104, no. 3, 2002, pp. 765-775.

Mmembe, Achille. Necropolitics. Translated by Steven Corcoran, Duke UP, 2019.

---. “Necropolitics.” Translated by Libby Meintjes, Public Culture, vol. 15, no. 1, 2003, pp. 11-40.

Morton, Stephen. “Terrorism, Orientalism and Imperialism.” Wasafiri, vol. 22, no. 2, 2007, pp. $36-42$

Naber, Nadine. "Look, Mohammed the Terrorist Is Coming!" Race and Arab Americans before and after 9/11: From Invisible Citizens to Visible Subjects, edited by Amaney A. Jamal, Syracuse UP, 2008, pp. 276-304.

"President Bush Visits Troops in Iraq," The White House, 13 June 2006. Accessed 27 March 2020. http://www.whitehouse.gov/news/releases/2006/06/20060613-2.html.

“President's Radio Address," The White House, 24 May 2008. Accessed 27 March 2020. http:// www.whitehouse.gov/news/releases/2008/05/20080524.html.

Said, Edward W. "Punishment by Detail." Monthly Review, October 2002. Accessed 4 September 2020, https://monthlyreview.org/2002/10/01/punishment-by-detail/.

---. Covering Islam: How the Media and the Experts Determine How We See the Rest of the World. Vintage Books, 1997.

---. "The Essential Terrorist." Blaming the Victims: Spurious Scholarship and the Palestinian Question, edited by Edward Said and Christopher Hitchens, Verso, 1988, pp. 149-58.

---. Orientalism. Vintage Books, 1979. 
Saldívar, Ramón. "Historical Fantasy, Speculative Realism, and Postrace Aesthetics in Contemporary American Fiction.” American Literary History, vol. 23, no. 3, 2011, pp. 574-599.

Shaheen, Jack G. Guilty: Hollywood's Verdict on Arabs after 9/11. Olive Branch, 2008.

---. "Reel Bad Arabs: How Hollywood Vilifies a People." The Annals of the American Academy of Political and Social Science, vol. 588, no. 1, 2003, pp. 171-193.

---. Reel Bad Arabs: How Hollywood Vilifies a People. Olive Branch, 2001.

Shryock, Andrew. Islamophobia/Islamophilia: Beyond the Politics of Enemy and Friend. Indiana UP, 2010.

Spivak, Gayatri Chakravorty. "Deconstructing Historiography." Deconstruction: Critical Concepts in Literary and Cultural Studies, vol. 4, 2003, p. 220.

Syriana. Directed by Stephen Gaghan, Warner Bros, 2005.

"Syriana." Wikipedia: The Free Encyclopedia, Wikimedia Foundation Inc. Accessed 4 September 2020. https://en.wikipedia.org/wiki/

Syriana\#: :text=In\%20a\%20December\%202005\%20interview,Empire)

\%20that\%20ensured\%20continued\%20western.

“The Last Night Letter," September 2011. Accessed 4 September 2020. https://www.

911memorial.org/sites/default/files/inline-files/2001\%20sept.

10\%20the\%20Last\%20Night\%20Letter_0.pdf.

\section{NOTES}

1. Islamophobia without Islamophobes in the title of my essay is inspired by Eduardo Bonilla-Silva's Racism Without Racists: Color-blind Racism and the Persistence of Racial Inequality in the United States.

2. "Failing to account for the law's role in authorizing and executing Islamophobia overlooks the relationship state actors have to the hateful violence of individual bigots, and it ignores the reality that the state enlists private citizens to partake in the national project of identifying and punishing individuals stereotyped as presumptive terrorists" (Beydoun 19).

3. See also Saldívar, Ramón. "Historical Fantasy, Speculative Realism, and Postrace Aesthetics in Contemporary American Fiction.” American Literary History, vol. 23, no. 3, 2011, pp. 574-599.

4. I am referring to G.W. Bush's dividing the world into 'with us' or 'with the terrorist.'

5. I read the film's title, Syriana as a combination of Syria, Iran and Saudi Arabia. "In a December 2005 interview, Baer told NPR that the title is a metaphor for foreign intervention in the Middle East, referring to post-World War II think tank strategic studies for the creation of an artificial state (such as Iraq, created from elements of the former Ottoman Empire) that ensured continued Western access to crude oil. The movie's website states that '“Syriana' is a real term used by Washington think-tanks to describe a hypothetical reshaping of the Middle East" (Wikipedia).

6. Referring to Giorgio Agamben's concept of "bare life."

7. The author of the manifesto is not clear as of today, but it has been written by one of the terrorists. It was translated into English along with commentaries by Kanan Makiya and Hassan Mneimneh

8. "President Bush Visits Troops in Iraq," 13 June 2006; "President's Radio Address," 24 May 2008. 
9. Gayatri Spivak discusses this idea of metalepsis in "Deconstructing Historiography" (341).

10. Timothy James McVeigh was a Gulf War veteran who planned and executed the 1995 Oklahoma City bombing that killed 168 people and left over 680 others injured.

11. Andres Behring Breivik also known as Andrew Berwick is a Norwegian far-right terrorist who committed the terrorist attacks on 22 July 2011 in Norway that killed 77 people.

12. Furthermore, such "irrationality" of violence is said to be motivated by the terrorists' perception that civilian populations in the West are "complicit" with their state policies against them (Malreddy 4).

\section{ABSTRACTS}

This paper investigates the geopolitical context of the emergence of "suicide terrorism" to propose that terrorism in its various forms has less to do with religious ideologies in general and with Islamic faith in particular, and more to do with the colonial and neocolonial politics of Empire in the colonies, postcolonies and occupied territories by the U.S. army and its allies in the Middle East in the post-9/11 era. Two representations of the figure of the suicide terrorist will be analyzed as they are presented in the narratives suggested in the Showtime series Homeland (2011-) and the film Syriana (2005). I argue that even though the Islamicate world and Muslims in the post-9/11 era have generally been portrayed in a differentiated fashion, these media productions have had almost the same effects on the public as earlier Orientalist productions. Although they appear to endorse antiracism and multiculturalism on the surface, these current narratives simultaneously produce what Evelyn Alsultany calls "the logics and affects necessary to legitimize racist policies and practices" (Alsultany 162). A "dialectical Islamophobia" (Beydoun 40) that is at play in the West and Western media productions legitimizes and values imperialist necropolitics while delegitimizing its opponent, namely the religious necropolitics of suicide terrorism.

INDEX

Keywords: Islamophobia, Necropolitics, Orientalism, New Terrorism, Suicide Terrorist, “War on Terror"

\section{AUTHOR}

\section{MAHMOUD ARGHAVAN}

Mahmoud Arghavan is an independent scholar from Iran residing in Munich. He completed his $\mathrm{PhD}$ in American Studies at Free University of Berlin in 2013 with a dissertation entitled "Iranian American Literature: From Collective Memory to Cultural Identity." Since 2016 he has been working as coordinator for the Unit of Aid for Refugees, Migration, and Integration at Innere Mission in Munich. His research interests include Diaspora Studies, Postcolonial Studies, Critical 
Race Theory, Border Studies, Global Warming and Climate Refugees. He has authored the article "Postcolonial Orientalism: A Study of the Anti-Imperialist Rhetoric of Middle Eastern Intellectuals in Diaspora" in the edited collection Postcolonial Justice (Brill, 2017), and co-written the article "Writing against Neocolonial Necropolitics: Literary Responses by Iraqi/Arab Writers to the US 'War on Terror'," which appeared in a special issue on "Global Responses to the "War on Terror"' in the European Journal of English Studies (2018). He has also co-edited the volume Who Can Speak and Who Is Heard/Hurt?: Facing Problems of Race, Racism, and Ethnic Diversity in the Humanities in Germany(transcript April 2019). 